\title{
Telework and Work-Family Conflict during COVID-19 Lockdown in Portugal: The Influence of Job-Related Factors
}

\author{
Cláudia Andrade 1,2,*(D) and Eva Petiz Lousã ${ }^{3,4}$ \\ 1 College of Education (ESEC-IPC), Polytechnic of Coimbra, 3000-329 Coimbra, Portugal \\ 2 Center for Psychology (CPUP), University of Porto, 4200-135 Porto, Portugal \\ 3 Centre for Organisational and Social Studies of Polytechnic of Porto (CEOS.PP, ISCAP), Polytechnic of Porto, \\ 4465-004 São Mamede de Infesta, Portugal; evapetiz@iscap.ipp.pt \\ 4 Unidade de Investigação em Ciências Empresariais e Sustentabilidade (UNICES), University of Maia, \\ 4475-690 Maia, Portugal \\ * Correspondence: mcandrade@esec.pt
}

Citation: Andrade, Cláudia, and Eva Petiz Lousã. 2021. Telework and Work-Family Conflict during COVID-19 Lockdown in Portugal: The Influence of Job-Related Factors. Administrative Sciences 11: 103. https://doi.org/10.3390/admsci 11030103

Received: 22 July 2021

Accepted: 10 September 2021

Published: 18 September 2021

Publisher's Note: MDPI stays neutral with regard to jurisdictional claims in published maps and institutional affiliations.

Copyright: (c) 2021 by the authors. Licensee MDPI, Basel, Switzerland. This article is an open access article distributed under the terms and conditions of the Creative Commons Attribution (CC BY) license (https:// creativecommons.org/licenses/by/ $4.0 /)$.

\begin{abstract}
Even though research has been showing that telework, under regular circumstances, could benefit the integration of work and family life, mandatory telework during the COVID-19 lockdown brought additional challenges, with potential to create conflicts between work and family spheres. Using regression analysis, this study examined the contribution of demographic and jobrelated variables to the prediction of work-family conflict among a sample of 213 workers who were involved in mandatory telework during the first lockdown due to the COVID-19 pandemic. The results revealed that role overload, after-hours work-related technology use, and low job autonomy accounted for the prediction of work-family conflict. Support from the supervisors and coworkers did not have an impact in easing the perception of work-family conflict but presented a moderation effect between after-hours work-related technology use and work-family conflict. Implications of the study for management practices related to telework, limitations of the study, and directions for future research are discussed.
\end{abstract}

Keywords: telework; work-family conflict; COVID-19

\section{Introduction}

Telework is not a new working mode. Since Jack Nilles introduced the concept of "telecommuting" in the 1970s, this flexible working mode has begun to gain increasing popularity as an alternative to the traditional working style (Ruiller et al. 2019; Santana and Cobo 2020; Yu et al. 2019). The concept of telework can be understood as performing work in a remote location or far from its central offices or production facilities, where workers can communicate with coworkers through communication and information technologies (Gupta et al. 1995; Bentley et al. 2016) or ICT-mobile work, using technologies such as smartphones, tablets, laptops, and desktop computers (Messenger et al. 2017). This type of work can take place in a variety of settings, such as satellite offices, tele centers, professional workspaces, public spaces, and, often, workers' homes (Donnelly and Proctor-Thomson 2015). While in some countries, teleworking is widespread, it has not been traditionally used in Portugal. In 2019, only 6.5\% of Portuguese workers were working from home (Eurostat 2019).

The COVID-19 pandemic was declared by the World Health Organization (World Health Organization WHO) on 11 March 2020, and on 13 March 2020, the Portuguese government declared a state of alert, which forced the closure of schools and businesses to contain the spread of the SARS-CoV-2 virus. In Portugal, like in other European countries, from March 2020, due to the pandemic situation of COVID-19, the government made teleworking mandatory, and there has been a large-scale teleworking experiment since then in many countries (Howe et al. 2020; ILO 2021). Since virtual work has become 
crucial for the survival of organizations (Howe et al. 2020), organizations have had to develop conditions and make a swift transition to allow individuals to work from home when practicable (using communication platforms such as Zoom, Adobe Connect, and MS Teams), independently of their previous teleworking experience (Biron et al. 2021). The previously gathered knowledge about teleworking was mainly derived from a context in which teleworking was only used sporadically or rarely and was only used by some, but not all or most, employees inside a company. The unusual circumstances of forced telework in the COVID-19 lockdown caused a shift in the working context. Under normal circumstances, teleworking has shown benefits for its users, allowing a better balance between work and family (Vilhelmson and Thulin 2016), although some studies have also identified some negative impacts on work-life balance (Felstead and Henseke 2017). In fact, researchers within the Portuguese context have consistently found that, under normal circumstances, the management of work and family roles is difficult, with Portuguese workers often reporting high levels of work-family conflict (Matias et al. 2012; Perista et al. 2016). During the COVID 19 pandemic, the boundaries between work and personal life brought additional challenges, potentially generating conflict between professional and personal life, providing a new context for expanding our knowledge in this field. With this work we analyze potential factors, namely those related to the work context, to understand how job-related variables can predict workers' perception of work and family during mandatory telework. We review the current research to establish a theoretical framework, incorporating job-related factors that might have an influence on teleworkers' performance during the COVID-19 lockdown and may generate a work-family conflict. We focus on job-related factors, such as role overload, job autonomy, after-hours work-related technology use, and supervisor support from coworkers and supervisors. To explore deeper the potential buffer effects of work-related forms of support, such as supervisor and coworker support, we also considered the moderation effects of supervisor and coworker support on the relation between after-hours work-related technology use and work-family conflict.

\section{Theoretical Background}

Work-life balance and its relation to telework was an issue specifically addressed in a recent Eurofound study (Vargas-Llave and Weber 2020). According to that study, Portugal is one of the countries in which telework has been promoted to support conciliation between work and family or personal life without dealing with any of the associated negative consequences. In Portugal, before the outbreak of COVID 19, there was a specific legislation (governed by the Portuguese Employment Code, i.e., a special type of employment contract that must be agreed in writing by the employer and the employee) on the use of telework that established "that telework can be used as one of the measures to improve work-life balance" (European Agency for Safety and Health at Work 2021, p. 12). Although there was an increase in teleworkers since 2009, prior to the pandemic, "very few collective agreements deal with telework" (European Agency for Safety and Health at Work 2021, p. 14). After COVID-19, teleworking became compulsory and applied with no need for a written agreement; (i) for employees whose personal situation allowed them to do so and (ii) whose roles were compatible with remote working. Thus, the implications of these forms of working need more research in the Portuguese context.

The effects of teleworking on personal and professional life balance are somehow contradictory and paradoxical (Boell et al. 2016; Messenger 2019; Piszczek 2017). Telework has been investigated in the literature as a flexible work modality with potential benefits for workers to manage work-family needs (Gajendran and Harrison 2007), and in this sense, as a means of lessening work-family conflict (Madsen 2003). However, there are several discrepancies in the studies (e.g., Allen et al. 2013; Gajendran and Harrison 2007), and as Allen et al. (2015) denote, there are moderators that influence the link between teleworking and work-family conflict. 
Generally, telework is a work option that allows flexibility in the place and on the schedule where the work is performed. While most investigations come from contexts in which workers are somehow able to decide to use this modality, the mandatory teleworking during the Covid lockdown forced workers to work from home (Anderson and Kelliher 2020). Research by Gonçalves et al. (2021) pinpoints that the economic crisis that Portugal went through a decade ago might account for the explanation of why Portuguese companies were somehow ready to make adaptations when facing a new crisis, with teleworking being a notable response to the pandemic situation (Gonçalves et al. 2021) Thus, while workers had to quickly adapt to new circumstances at work, often without a management and regulatory structure concerning how telework could be accomplished (ILO 2021), the lack of organizational support during this work transition could influence their work-life wellness (Como et al. 2021). Teleworkers, particularly those with children or other dependents at home, had to combine their professional commitments with their personal life during the pandemic outbreak. In fact, as pointed out by Kreiner (2006), individuals may have experienced tensions related to the demands associated with both professional and family roles, and to cope with the demands related to each role, in a satisfactory manner, they might have needed to manage the role boundaries actively. The loss of boundaries between work and family roles might have accounted for the perception of work-family conflict. Moreover, in their daily lives, to complete family support activities, many workers required additional time to complete their work tasks, whether by starting work early or working late (ILO 2021). A recent study by Tavares et al. (2021) confirmed that Portuguese workers during mandatory telework felt overworked in high percentages. Therefore, it is likely that the teleworkers sensed that they were exposed to a greater amount of work, as well as that they had to work beyond the hours that were usually defined by their working hours, increasing their experiences of work-family conflict. In fact, research done in Portugal during the pre-pandemic period by Andrade and Matias (2021) showed that the use of ICT during off-job time for work purposes increased the perception of technology use in family conflict. While teleworking during the COVID-19 pandemic, the dual stressors of work and family make the work-family conflict more evident since blurring of role boundaries will likely occur more often.

\section{Work-family conflict}

The integration of work and family roles has shown that demands and problems in one life domain often spillover into the other, often creating inter-role conflicts. Hence, inter-role conflict between work and family domains occurs when "role pressures from the work and family domains are mutually incompatible in some respect" (Greenhaus and Beutell 1985, p. 77). Work-family conflict is a type of inter-role conflict that arises when the demands and responsibilities of work and family interfere with each other (Byron 2005). According to Grzywacz and Marks (2000), work-family conflict involves two distinct sources: time pressure when work demands spillover into family life (work interference with family) or when family life spills over into work (family interference with work). In a meta-analysis that examined the negative consequences of work-family conflict, Amstad et al. (2011) found work-related outcomes (e.g., low levels of job satisfaction, burnout, intention to turnover, and increased absenteeism levels), family-related outcomes (e.g., low levels of marital and family satisfaction), and health-related outcomes (e.g., depression, anxiety, and psychological strain). Allen et al. (2000) and a review by Bellavia and Frone (2005) found that work-family conflict is one the most important and commonly found work-related stressors.

2. Job-related factors and role overload

Research on telework has shown that those who work from home tend to work longer hours than when working at the company's premises (Felstead and Henseke 2017). According to Felstead and Henseke (2017), remote workers seem to be willing to work longer and longer due to enthusiasm for work and job satisfaction, which brings benefits to the organization, but has negative impacts on work-life balance. This pressure felt by 
employees to do more work provokes a sense of not being able to finish what they must do. Duxbury and Halinski (2014) analyzed the relationship between hours of telework and role overload, suggesting that the total hours of work per week have a positive association with work role overload. Role overload was defined by Bacharach et al. (1990) as the perception of an individual when he or she cannot complete the tasks assigned to him or her in the professional domain due to time constraints, generating a conflict between the demands of time and the organization regarding the amount of work to be done. This concept is distinct from role conflict, which, in turn, refers to incompatible role requirements within the role (Bacharach et al. 1990). Since role overload is generally thought to induce strain (Karasek 1979), in line with several studies (e.g., Frone et al. 1997; Parasuraman et al. 1996), role overload is expected to have an impact on the conflict between work and family.

Hypothesis 1 (H1). Role Overload increases perceived work-family conflict.

3. After-hours work-related technology use

Previous studies suggest that telework can lead to an extension of working hours and more work at night and during weekends (ILO 2021; Messenger 2019). The abrupt imposition of COVID-19-related telework and the inexperience of most organizations in the management of this type of work led to many teleworkers being exposed to longer working hours (ILO 2021). Studies suggest that the use of technology (e.g., use of electronic e-mail communication, use of smartphones, laptops) intensifies work (e.g., Fender 2010; Piszczek 2017), also due to its use after working hours. The concept of after-hours electronic communications expectations was defined by Fender (2010), referring to the degree to which an employee perceives the organization to require him or her to be available to undertake technology-based work outside of normal working hours and locations. Piszczek (2017) expanded on Fender's (2010) definition of cell and smart phone technology to include a broader kind of electronic communication. While Jostell and Hemlin (2018) found that after-hours teleworking is not as troublesome in terms of work-family conflict as some prior studies have suggested, the imposition of this work modality, such as during the lockdown, can have a detrimental impact on this relationship. Therefore, it is reasonable to predict that workers who have no experience with telework will perceive an increase in after-hours work-related technology use, which will have repercussions for work-family conflict.

Hypothesis 2 (H2). After-hours work-related technology use increases perceived work-family conflict.

\section{Job Autonomy}

Autonomy at work, according to Hackman and Oldham (1975), refers to the degree to which a job provides the worker with the freedom and independence of being able to program and determine the procedures to be performed. In this sense, a worker feels that he or she can make his or her own decisions about daily work activities and decide on the pace and working methods (De Witte et al. 2007). This perception of control that the worker has over his or her work influences work planning, work speed, and goal setting (Chung 2017). A higher level of autonomy at work can reduce the conflict between family work, as suggested by studies conducted in salaried workers (Voydanoff 2004) and teleworkers (Goldstein 2003). This reduction in the conflict between family work may be because employees believe that they have the necessary competence and capabilities to achieve their job performance (Saragih 2011). Thompson and Prottas (2006) found that low job autonomy significantly related to job stress, turnover intention, and work and family conflict. From this point of view, the present study formulates the following hypothesis:

Hypothesis 3 (H3). Job autonomy decreases perceived work-family conflict.

5. Work-related support: supervisor support and coworkers' support 
Kossek et al. (2011) identified two types of supervisor support: the instrumental support, where supervisors give tangible assistance to increase workers' performance and well-being, and emotional support, translated into expressions of concern about the worker's well-being. Concerning the relation between supervisor support and work-family conflicts, some authors found that supervisors can have behaviors that ease or help to solve workers' work-family conflicts (Kossek et al. 2016) or attitudes, such as understanding the workers' needs towards work-family integration, acting in ways that improve this relation (Thomas and Ganster 1995). Coworkers' support has been found to decrease individuals' negative feelings about work (Baker et al. 1996), reduce stress at work, and decrease physiological strain and depression (Ladd and Henry 2000). However, because teleworkers do not share the same workspace, they may feel isolated at work as a result of less contact and communication with their coworkers (Greer and Payne 2014) and lose out on the most common social interactions with coworkers (Morganson et al. 2010). They must, on the other hand, invest in the cooperation because they may not be present when the entire team has to get together to exchange ideas and solve problems (Pérez Pérez et al. 2004). Despite substantial research focusing on the importance of positive interpersonal relationships for individuals' functioning and psychological well-being, research aiming to analyze the impacts of coworkers' support on work-family conflict remain sparse and report inconsistent findings. While some studies have reported significant negative correlations between coworker support and work-family conflict (Bernard and Phillips 2007), others have reported weak or even null correlations with work-family conflict (Frone et al. 1997; Reifman et al. 1991). As pointed out by Mesmer-Magnus and Viswesvaran (2009), the effects of coworker support in reducing work-family conflict have primarily centered on emotional support that is created by positive relationships. However, quite often, instrumental assistance given by coworkers (e.g., covering for job duties when a family member needs assistance, swapping work schedules) can be important to ease work-family conflict (Mesmer-Magnus and Viswesvaran 2009). As such, we formulated the following hypothesis:

Hypothesis 4 (H4). Work-related supervisor support decreases perceived work-family conflict.

Hypothesis 5 (H5). Work-related support from coworkers decreases perceived work-family conflict.

6. After-hours work-related technology use and work-family conflict: supervisor and coworker support as moderators

Drawing from research that relates the use of ICT for work purposes during off-job time and work-non work tensions due to this use, individual differences are reported by the studies (Andrade and Matias 2021; Duxbury et al. 1996; Derks et al. 2016). In fact, requests to answer calls or accomplish work tasks during off-job time can lead individuals to struggle to have control over their work and family roles, for some creating work-family conflict (Andrade and Matias 2021; Chen et al. 2009). Fender (2010) claims that off-job communications using ICT creates in the individuals the perception that the organizations require from them to respond to communications or to perform work-related tasks during off-job time, often when individuals are in their family sphere. As Piszczek (2017) points out, the norms for the use of technology develop informally at the organization level and this can influence individual behavior during off-job time. Moreover, these norms can be enacted through supervisors and coworkers (Fenner and Renn 2010; Piszczek 2017). In some cases, this happens because individuals perceive that they must fulfill organizational expectations of availability during off-job time, but this message could become reinforced if they received these calls from supervisors or coworkers.

Thus, we expect that after-hours work-related technology use can impact work-family conflict differently via work-family social support (supervisor support and coworkers' support). 
Hypothesis 6 (H6). Supervisor support will moderate the relationship between after-hours workrelated technology use and work-family conflict.

Hypothesis 7 (H7). Coworker support will moderate the relationship between after-hours workrelated technology use and work-family conflict.

\section{Method}

\subsection{Data Collection and Sample}

The data for this study were collected as a part of a larger project examining the effects of mandatory telework during the first COVID-19 lockdown. The sample consisted of 212 participants that met inclusion criteria: working full-time in the private or public sector. Google forms was used to collect survey responses and participants were informed about the goals of the research project, and both confidentiality and anonymity was assured. Most respondents in our sample were female $(71.7 \%)$, aged between 18 and 64 years old $($ Mage $=37.35, \mathrm{SD}=11.68), 69.3 \%$ had a university degree, $29.7 \%$ completed high school/vocational training, $0.9 \%$ had elementary education, and $52.8 \%$ were parents. They worked in public institutions (42.5\%), private institutions (45.3\%), and were self-employed $(12.3 \%)$.

\subsection{Measures}

Work-Family Conflict: The construct was measured using 3 items capturing the time experienced by study participants adapted from Matthews et al. (2011). Sample items included "Due to my work responsibilities, I'm not able to spend the time with my family that I would like". Respondents were asked to agree or disagree with each item $(1=$ strongly disagree and $5=$ strongly agree). The internal consistency for work-family conflict was $\alpha=0.93$ (three items).

Role Overload: This construct was measured by using 3 items from the scale developed by Bacharach et al. (1990). A sample item was "I do not have time to finish my work". Respondents were asked to agree or disagree with each item $(1=$ strongly disagree and $5=$ strongly agree). Internal consistency was $\alpha=0.87$.

Job Autonomy: This construct was measured using 5 items adapted from Rosenthal et al. (1996). A sample item was "I feel that I can plan my work". Respondents were asked to agree or disagree with each item $(1=$ strongly disagree and $5=$ strongly agree). Internal consistency was $\alpha=0.89$.

After-hours work-related technology use: This construct was measured using an adapted version of the scale of Piszczek (2017). A sample item was "I had to answer calls from work after my work hours". Respondents were asked to agree or disagree with each item $(1=$ strongly disagree and $5=$ strongly agree). Internal consistency was $\alpha=0.89$.

Work-Family Social Support: This construct was measured by 6 items adapted from Boyar et al. (2003) measuring work-related support from the supervisor and the coworkers. A sample item for work-related support from the supervisor was "My supervisor is understanding or sympathetic on the job" and a sample item for work-related support from the coworkers was "My coworkers help me to figure out how to solve work problems". Respondents were asked to agree or disagree with each item $(1=$ strongly disagree and $5=$ strongly agree). Internal consistency for each scale was, respectively, $\alpha=0.91$ and $\alpha=0.89$.

\subsection{Data Analysis Procedure}

The statistics software SPSS 25 was used to perform descriptive data analysis, Pearson correlations were tested to detect relationships between the variables, and Cronbach's alpha coefficient was calculated to verify the scales' reliability in the whole sample. Pearson correlation coefficients were calculated to examine linear association between study variables. As a first step, correlations between the demographic and the outcome variable were calculated. As a second step, correlations between predictor variables and the outcome 
variable, work-family conflict, were calculated. As a third step, all variables that were considered job-related factors were regressed onto work-family conflict.

The hypothesized model for moderation analysis was done with the Macro PROCESS (Hayes 2013; Preacher and Hayes 2008).

\section{Results}

Correlations between the demographic and the outcome variable were calculated. Neither age, gender, nor having children were significantly correlated with work-family conflict. After, as a second step, correlations between predictors variables and the outcome variable, work-family conflict, were calculated (Table 1 ).

Table 1. Means, standard deviations, and intercorrelations.

\begin{tabular}{|c|c|c|c|c|c|c|c|c|}
\hline Variables & $M$ & $S D$ & 1 & 2 & 3 & 4 & 5 & 6 \\
\hline 1. Work-family conflict & 4.43 & 1.32 & - & & & & & \\
\hline 2. Role overload & 4.00 & 1.15 & $0.36 * *$ & - & & & & \\
\hline 3. Job autonomy & 2.13 & 1.85 & $0.48^{* *}$ & $0.31 *$ & - & & & \\
\hline 4. After-hours technology use & 4.07 & 0.76 & $0.46^{* *}$ & $0.39 * *$ & $0.42 * *$ & - & & \\
\hline 5. Supervisor support & 3.11 & 0.79 & -0.39 * & -0.27 & 0.24 & -0.17 & - & \\
\hline 6. Coworkers' support & 3.14 & 1.34 & -0.32 * & -0.24 & 0.25 & -0.28 & $0.32 *$ & - \\
\hline
\end{tabular}

In the regression model, all variables that were considered job-related factors were regressed onto work-family conflict, controlling for age and having children, while jobrelated factors accounted for significant variance in work-family conflict $\left(\Delta R^{2}=0.39\right.$, $F 5,34=8.97, p<0.001$; Table 2). Specifically, role overload $(\beta=0.45, p<0.001)$, job autonomy $(\beta=-0.37, p<0.001)$, and after-hours work-related technology use $(\beta=0.42, p<0.001)$ were significantly associated with work-family conflict. No other variables were significantly related to work-family conflict (Table 2).

Table 2. Predictors of work-family conflict.

\begin{tabular}{lccccc}
\hline \multicolumn{1}{c}{ Predictors } & $\boldsymbol{R}^{\mathbf{2}}$ & $\boldsymbol{B}$ & $\boldsymbol{S E}$ & $\boldsymbol{t}$ & $\boldsymbol{p}$ \\
\hline Step 1 & 0.08 & & & & \\
Age & & -0.18 & 0.13 & -1.45 & 0.23 \\
Having Children & & 0.32 & 0.15 & -1.12 & 0.17 \\
Step 2 & 0.37 & 0.45 & 0.23 & 0.24 & $<\mathbf{0 . 0 0 1}$ \\
Role overload & & -0.37 & 1.21 & -0.27 & $<\mathbf{0 . 0 0 1}$ \\
Job autonomy & & 0.42 & 1.33 & 1.34 & $<\mathbf{0 . 0 0 1}$ \\
After-hours tech use & & -0.23 & 0.35 & 0.75 & 0.32 \\
Supervisor support & -0.24 & 0.26 & 0.48 & 0.21 \\
Coworkers support & & & &
\end{tabular}

Note. Bold font indicates significant finding.

The testing of the moderation model using the Process macro revealed that supervisor support has a main effect on work-family conflict (Tables 3 and 4). Additionally, after-hours work-related technology use has a main effect on work-family conflict (i.e., after-hours work-related technology use is linked positively with work-family conflict). No interaction effect between after-hours work-related technology use and supervisor support was found. The model explained around $28 \%$ of variance $\left(R=0.52 ; R^{2}=0.28 ; p<0.001\right)$. Moreover, coworker support has a main effect on work-family conflict. No interaction effect between after-hours work-related technology use and coworker support was found. The model explained around $17 \%$ of variance $\left(R=0.32 ; R^{2}=0.17 ; p<0.001\right)$ (Figures 1 and 2$)$. 
Table 3. Moderation Model results for supervisor support.

\begin{tabular}{|c|c|c|c|c|c|}
\hline & $B$ & $S E$ & $T$ & Lower Bound CI & Upper Bound CI \\
\hline After-hours work-related technology use * & 0.42 & 0.13 & 10.30 & -0.04 & 0.37 \\
\hline Supervisor support & -0.28 & 0.12 & -10.40 & -0.33 & -0.06 \\
\hline $\begin{array}{c}\text { After-hours work-related technology use * } \\
\text { supervisor support }\end{array}$ & -0.09 & 0.17 & -0.59 & -0.29 & 0.30 \\
\hline Gender & 0.11 & 0.16 & 10.26 & -0.16 & 0.31 \\
\hline Having Children & 0.12 & 0.18 & 10.12 & -0.19 & 0.32 \\
\hline
\end{tabular}

Notes. $\mathrm{CI}$ = confidence interval; $\mathrm{SE}=$ standard error. Bolded text indicates a significant effect; estimates are significant if the CI does not contain zero. ${ }^{*}$ moderation.

Table 4. Moderation Model results for coworker support.

\begin{tabular}{|c|c|c|c|c|c|}
\hline & $B$ & $S E$ & $T$ & Lower Bound CI & Upper Bound CI \\
\hline After-hours work-related technology use * & 0.42 & 0.13 & 10.30 & -0.04 & 0.37 \\
\hline Coworker support & -0.24 & 0.15 & -10.34 & -0.36 & -0.07 \\
\hline $\begin{array}{c}\text { After-hours work-related technology use * } \\
\text { supervisor support }\end{array}$ & -0.07 & 0.15 & -0.49 & -0.22 & 0.28 \\
\hline Gender & 0.11 & 0.16 & 10.26 & -0.16 & 0.31 \\
\hline Having Children & 0.12 & 0.18 & 10.12 & -0.19 & 0.32 \\
\hline
\end{tabular}

Notes. $\mathrm{CI}$ = confidence interval; $\mathrm{SE}$ = standard error. Bolded text indicates a significant effect; estimates are significant if the CI does not contain zero. * moderation.

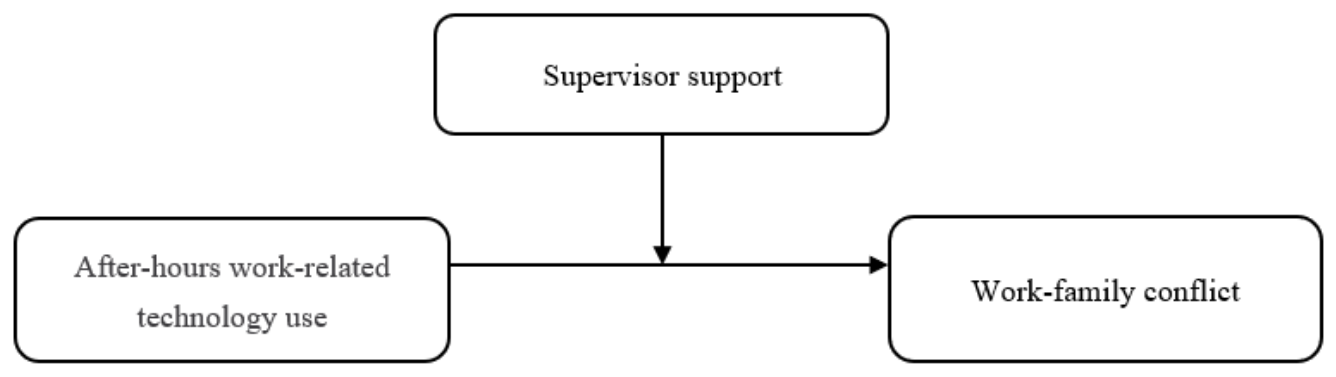

Figure 1. Relationship between after-hours work-related technology use, supervisor support, and work-family conflict.

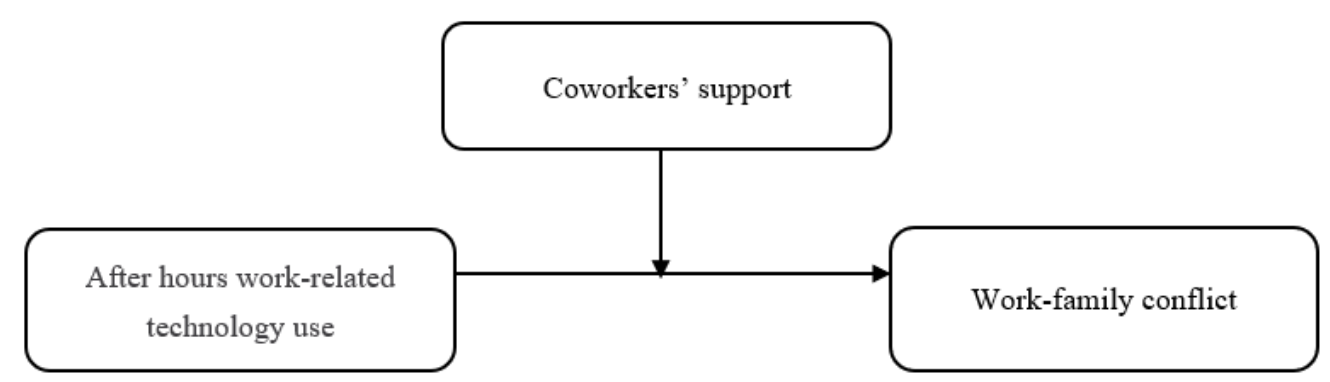

Figure 2. Relationship between after-hours work-related technology use, coworkers' support, and work-family conflict.

\section{Discussion}

Drawing on research about telework, the present study aimed to expand our knowledge about the implications of job-related factors associated with telework on the perceptions of work-family conflict, under the unique circumstances of mandatory telework in the COVID-19 lockdown. As anticipated, the test of a model allowed us to identify role overload, after-hours work-related technology use, and low job autonomy as predictors of work-family conflict. Our findings indicate that, in line with previous research, when workers have too many work-related demands, they might experience strain, and this can increase their perception of work-family conflict (Voydanoff 2004). Even though previous 
studies also identified this relation, this finding is particularly relevant since the transition to teleworking, due to the COVID-19 lockdown, seemed to have accounted for this perception of role overload. Our model also predicted the role of after-hours work-related technology use in work-family conflict. Much like recent research examining the use of ICT during off-job time for work purposes, our findings call to attention the fact that some individuals, during telework, might struggle to have control over their work and family roles with potential to create work-family conflict (Chen et al. 2009; Andrade and Matias 2021). Another important predictor of work-family conflict was low job autonomy. The perception of control that the worker has over his or her work influences work planning, work speed, and goal setting, as pointed out by Chung (2017). Moreover, since studies have shown that a high level of autonomy at work can reduce the conflict between family and work (Goldstein 2003; Voydanoff 2004), this is an important dimension to be considered when work is shifted to telework. While support from the supervisors and from coworkers did not predict the work-family conflict, they proved to have a moderating effect on after-hours work-related technology use and work-family conflict. These results suggest that while after-hours work-related technology use is related with work-family conflict, supervisors and coworkers can have an important role in easing this perception. In this way, this study calls for more precise alignment not only related to tasks and autonomy levels (e.g., better control of work planning, work speed, and goal setting), which could be improved by organizations and managers, but also to the importance of work-related forms of support in moderating the effects of work factors that can create strain and work-family conflict. Our findings are in line with research about organizational support practices that showed a positive impact on these practices of workers' perceptions of control over their work, as well as family issues (Allen et al. 2015; Thomas and Ganster 1995).

\section{Conclusions}

Due to the pandemic situation of COVID-19, teleworking became mandatory in March 2020 in Portugal. As such, many companies and public institutions had to move their workforce, when possible, to telework. Thus, employees had to adapt quickly to this new form of work and, in the case of workers with children, they also had to adjust to working from home and dealing with other family tasks, such as helping children with remote school tasks and classes, often feeling that work and family roles conflicted (Tavares et al. 2021). This unprecedented situation of mandatory telework caused by the COVID-19 pandemic forced quick adjustments of both organizations and employees, questioning some of the negative and positive aspects that have been found in literature about teleworking under normal circumstances. In line with research by Hammer et al. (2005), one of the main explanations for why telework does not help reduce work-life conflict is related to the loss of boundaries between work and family domains, with an increase in family responsibility that can amplify the conflict between these two roles. This was the scenario for many workers during the lockdown. In this sense, the present study aimed to better understand how job-related variables predict work-family conflict among a sample of workers who were involved in mandatory telework during the first lockdown due to the COVID-19 pandemic. The results of the regression reveal that jobrelated factors, such as role overload, after-hours work-related technology use, and low job autonomy, accounted for the prediction of work-family conflict. Support from supervisors and coworkers did not have an impact on easing the perception of work-family conflict but presented a moderation effect between after-hours work-related technology use and work-family conflict.

Overall, the current study contributes to the debate about the job-related factors that, during mandatory teleworking due to the pandemic COVID-19, were related to work-family conflict. As some companies might adopt teleworking practices in the postCOVID-19 era, it is important to rethink strategies that can create work-remote settings without harming the work and family relationships of their employees. Our research is also in line with a study carried out in Portugal about people management during 
the COVID-19 pandemic, which found that, among other dimensions, work-life balance should be considered a priority since telework has the potential to be a form of work in the post-pandemic work settings used more often (Gonçalves et al. 2021).

The present study indicates that mandatory telework, in contrast with optional telework, can be problematic for employees. For policy makers, it is important to note that the way telework is organized should be addressed in the future. As a result of downscaling, working at the office can be financially interesting for employers; therefore, they might retain telework to some extent, which can be detrimental to employees. Moreover, the implications of the study for management practices related to telework, limitations of the study, and directions for future research are presented in the following sections.

\subsection{Practical Implication for Organizations and Managers}

This study has several practical implications for organizations and managers in the management of people. While most organizations and managers were forced to make the transition to telework and use different technologies during the COVID-19 crisis, current research indicates that this will become a more common trend in the future of work (e.g., Gonçalves et al. 2021; Santana and Cobo 2020). Therefore, it is critical to develop effective people management strategies to maintain the essential balance between teleworker wellbeing and productivity (Golden and Gajendran 2019). Concerning job-related factors, organizations and managers can develop management strategies to ensure that teleworkers can plan their work, so that they know what activities to prioritize, which tasks to complete, and which deadlines to meet, preventing teleworkers from experiencing work overload. Additionally, organizations and people managers can support their workers by setting clear expectations regarding outputs, defining realistic objectives (Masuda et al. 2017), managing the remote team with a results-oriented strateg and offering flexibility to manage work schedules. The adoption of appropriate platforms that facilitate cooperation and knowledge sharing can help optimize the performance of individuals and teams (van der Lippe and Lippényi 2020), avoiding unnecessary coworker or superviso' disruptions and allowing everyone to access the information at the time they need it. The use of these platforms can not only reduce the impact of after-hours work-related technology use and provide teleworkers with better control over work-family boundaries (Piszczek 2017), but also give them a sense of more control and autonomy over aspects of their job responsibilities (Chung 2017), which will have repercussions on their well-being and productivity. Furthermore, for organizations that intend to offer telework in the future, people managers need to focus their efforts on organizational culture and support for the teleworking modality to be effective (Allen et al. 2015). The existence of a mutual agreement between workers and organizations for this type of work and the support of supervisors seeking to meet the individual needs of each employee (de Vries et al. 2019) is important to create a culture of trust between supervisors and workers (Allen et al. 2015; Golden and Gajendran 2019; Mesmer-Magnus and Viswesvaran 2009). Indeed, according to some studies, the lack of confidence can lead to excessive surveillance and monitoring efforts because of supervisors conducting not only an invasion of privacy in teleworkers' homes, as well as a greater effort on their part to work extensive hours, as they feel pressured to do so (Bathini and Kandathil 2020), which should be a practice to avoid. Another strategy to be highlighted in the management of people in the telework modality is to ensure teleworkers involvement, so that they can work together as a team and communicate, contributing to the maintenance of organizational cohesion, increasing coworker feelings of support, and lessening feelings of social isolation. We believe that these actions, especially those related to the development of feelings of belonging, and strategies of support workers might minimize the work-family conflict and contribute to a better balance between productivity and organizational well-being. 


\subsection{Limitations and Future Research Directions}

This study is not without limitations. Most notably, data was collected at the same time and from a single source, thus it is possible that a common method bias could skew some of the results (Podsakoff et al. 2003). Future research can address this concern by testing a model at two or more timepoints, with validation from other rating sources, if possible. It is also important to test possible mediators between job-related factors, such as those that were selected for this study, and their potential impact on work-family conflict, considering potential effects on the three types of work-conflict: behavior, time, and strain. Even though, in the present study, the model was tested with and without control variables, such as gender and having children, generating the same pattern of results, future studies with more gender-balanced and diverse samples (e.g., having preschool children or teenagers) and from a wide range of educational backgrounds and professions working in both the public and private sectors can provide a more comprehensive overview of the results. Furthermore, this study does not allow the comparison between the pre-pandemic and pandemic situation and uses a non-representative sample. Future studies are needed with both representative samples and using longitudinal panel data to further explore the relations between telework and work-life balance.

Author Contributions: Conceptualization, C.A. and E.P.L.; methodology, C.A.; software, C.A.; validation, C.A. and E.P.L.; formal analysis, C.A. and E.P.L.; investigation, C.A. and E.P.L.; resources, C.A.; data curation, C.A.; writing-original draft preparation, C.A. and E.P.L.; writing-review and editing, C.A. and E.P.L.; visualization, C.A. and E.P.L.; supervision, C.A.; project administration, C.A. All authors have read and agreed to the published version of the manuscript.

Funding: This research received no external funding.

Institutional Review Board Statement: The study was conducted according to the guidelines of the Declaration of Helsinki.

Informed Consent Statement: Informed consent was obtained from all subjects involved in the study.

Data Availability Statement: The data that support the findings of this study are available on request from the corresponding author, Cláudia Andrade, mcandrade@esec.pt.

Conflicts of Interest: The authors declare no conflict of interest.

\section{References}

Allen, Tammy D., David E. L. Herst, Carly S. Bruck, and Martha Sutton. 2000. Consequences associated with work-to-family conflict: A review and agenda for future research. Journal of Occupational Health Psychology 5: 278-308. [CrossRef]

Allen, Tammy D., Ryan C. Johnson, Kaitlin M. Kiburz, and Kristen M. Shockley. 2013. Work-family conflict and flexible work arrangements: Deconstructing flexibility. Personnel Psychology 66: 345-76. [CrossRef]

Allen, Tammy D., Timothy D. Golden, and Kristen M. Shockley. 2015. How Effective Is Telecommuting? Assessing the Status of Our Scientific Findings. Psychological Science in the Public Interest: A Journal of the American Psychological Society 16: 40-68. [CrossRef]

Amstad, Fabienne T., Laurenz L. Meier, Ursula Fasel, Achim Elfering, and Norbert K. Semmer. 2011. A meta-analysis of work-family conflict and various outcomes with a special emphasis on cross-domain versus matching-domain relations. Journal of Occupational Health Psychology 16: 151-69. [CrossRef] [PubMed]

Anderson, Deirdre, and Clare Kelliher. 2020. Enforced remote working and the work-life interface during lockdown. Gender in Management: An International Journal 35: 677-83. [CrossRef]

Andrade, Cláudia, and Marisa Matias. 2021. Work-related ICT use during off-job time, technology to family conflict and segmentation preference: A study with two generations of employees. Information, Communication $\mathcal{E}$ Society, 1-10. [CrossRef]

Bacharach, Samuel B., Peter Bamberger, and Sharon C. Conley. 1990. Work Processes, Role Conflict and Role Overload: The Case of Nurses and Engineers in the Public Sector. Work and Occupations 17: 199-228. [CrossRef]

Baker, Elizabeth, Barbara Israel, and Susan Schurman. 1996. Role of control and support in occupational stress: An integrated model. Social Science E Medicine 7: 1145-59. [CrossRef]

Bathini, Dharma Raju, and George Mathew Kandathil. 2020. Bother me only if the client complains: Control and resistance in home-based telework in India. Employee Relations 42: 90-106. [CrossRef]

Bellavia, Gina M., and Michael R. Frone. 2005. Work-family conflict. In Handbook of Work Stress. Edited by Barling Julian, E. Kevin Kelloway and Michael Robert Frone. Thousand Oaks: SAGE Publications, pp. 113-47. ISBN 0-7619-2949-5. 
Bentley, Tim Andrew, Stephen T. T. Teo, L. McLeod, F. Tan, Rachelle Bosua, and Marianne Gloet. 2016. The role of organisational support in teleworker wellbeing: A socio-technical systems approach. Applied Ergonomics 52: 207-15. [CrossRef]

Bernard, Miriam, and Judith E. Phillips. 2007. Working carers of older adults. Community, Work and Family 10: 139-60. [CrossRef]

Biron, Michal, Helen De Cieri, Ingrid Fulmer, Cai-Hui (Veronica) Lin, Wolfgang Mayrhofer, Margarita Nyfoudi, Karin Sanders, Helen Shipton, and Jian Min (James) Sun. 2021. Structuring for innovative responses to human resource challenges: A skunk works approach. Human Resource Management Review 31: 100768. [CrossRef]

Boell, Sebastian K., Dubravka Cecez-Kecmanovic, and John Campbell. 2016. Telework paradoxes and practices: The importance of the nature of work. New Technology, Work and Employment 31: 114-31. [CrossRef]

Boyar, Scott L., Carl P. Maertz Jr., Allison W. Pearson, and Shawn Keough. 2003. Work-family conflict: A model of linkages between work and family domain variables and turnover intentions. Journal of Managerial Issues 15: 175-90.

Byron, Kristin. 2005. A meta-analytic review of work-family conflict and its antecedents. Journal of Vocational Behavior 67: 169-98. [CrossRef]

Chen, Zheng, Gary N. Powell, and Jeffrey H. Greenhaus. 2009. Work-to-family conflict, positive spillover, and boundary management: A person-environment fit approach. Journal of Vocational Behavior 74: 82-93. [CrossRef]

Chung, Heejung. 2017. Work Autonomy, Flexibility, and Work-Life Balance Final Report. Canterbury: University of Kent.

Como, Rebecca, Laura Hambley, and José Domene. 2021. An exploration of work-life wellness and remote work during and beyond COVID-19. Canadian Journal of Career Development 20: 46-56.

de Vries, Hanna, Lars Tummers, and Victor Bekkers. 2019. The Benefits of Teleworking in the Public Sector: Reality or Rhetoric? Review of Public Personnel Administration 39: 570-93. [CrossRef]

De Witte, Hans, Elsy Verhofstadt, and Eddy Omey. 2007. Testing Karasek's learning and strain hypotheses on young workers in their first job. Work \& Stress 21: 131-41. [CrossRef]

Derks, Daantje, Arnold B. Bakker, Pascale Peters, and Pauline van Wingerden. 2016. Work-related smartphone use, work-family conflict and family role performance: The role of segmentation preference. Human Relations 69: 1045-68. [CrossRef]

Donnelly, Noelle, and Sarah B. Proctor-Thomson. 2015. Home-based teleworking in disasters. New Technology, Work and Employment 30: 47-61. [CrossRef]

Duxbury, Linda, and Michael Halinski. 2014. Dealing with the "Grumpy Boomers: Re-engaging the disengaged and retaining talent". Journal of Organizational Change Management 27: 660-76. [CrossRef]

Duxbury, Linda Elizabeth, Christopher Alan Higgins, and D. Roland Thomas. 1996. Work and family environments and the adoption of computer-supported supplemental work-at-home. Journal of Vocational Behavior 23: 1-23. [CrossRef]

European Agency for Safety and Health at Work. 2021. Regulating Telework in a Post-COVID-19 Europe. Luxembourg: Publications Office. [CrossRef]

Eurostat. 2019. Employed Persons Working from Home as a Percentage of the Total Employment, by Sex, Age and Professional Status. Luxembourg: European Statistical Office.

Felstead, Alan, and Golo Henseke. 2017. Assessing the growth of remote working and its consequences for effort, well-being and work-life balance. New Technology, Work and Employment 32: 195-212. [CrossRef]

Fender, C Melissa. 2010. Electronic Tethering: Perpetual Wireless Connectivity to the Organization. Philadelphia: Drexel University.

Fenner, Grant H., and Robert W. Renn. 2010. Technology-assisted supplemental work and work-to-family conflict: The role of instrumentality beliefs, organizational expectations and time management. Human Relations 63: 63-82. [CrossRef]

Frone, Michael R., John K. Yardley, and Karen S. Markel. 1997. Developing and Testing an Integrative Model of the Work-Family Interface. Journal of Vocational Behavior 50: 145-67. [CrossRef]

Gajendran, Ravi S., and David A. Harrison. 2007. The good, the bad, and the unknown about telecommuting: Meta-analysis of psychological mediators and individual consequences. Journal of Applied Psychology 92: 1524-41. [CrossRef] [PubMed]

Golden, Timothy D., and Ravi S. Gajendran. 2019. Unpacking the Role of a Telecommuter's Job in Their Performance: Examining Job Complexity, Problem Solving, Interdependence, and Social Support. Journal of Business and Psychology 34: 55-69. [CrossRef]

Goldstein, Nance. 2003. It at Work: Information Technologies and Remote Working in the United States. Arlington: SRI International.

Gonçalves, Sónia P., Joana Vieira dos Santos, Isabel S. Silva, Ana Veloso, Catarina Brandão, and Rita Moura. 2021. COVID-19 and People Management: The View of Human Resource Managers. Administrative Sciences 11: 69. [CrossRef]

Greenhaus, Jeffrey H., and Nicholas J. Beutell. 1985. Sources of conflict between work and family roles. Academy of Management Review 10: 76-88. [CrossRef]

Greer, Tomika W., and Stephanie C. Payne. 2014. Overcoming telework challenges: Outcomes of successful telework strategies. The Psychologist-Manager Journal 17: 87-111. [CrossRef]

Grzywacz, Joseph G., and Nadine F. Marks. 2000. Reconceptualizing the work-family interface: An ecological perspective on the correlates of positive and negative spillover between work and family. Journal of Occupational Health Psychology 5: 111-26. [CrossRef] [PubMed]

Gupta, Y. P., J. Karimi, and T. M. Somers. 1995. Telecommuting: Problems associated with communications technologies and their capabilities. IEEE Transactions on Engineering Management 42: 305-18. [CrossRef]

Hackman, J. Richard, and Greg R. Oldham. 1975. Development of the Job Diagnostic Survey. Journal of Applied Psychology 60: 159-70. [CrossRef] 
Hammer, L. B., M. B. Neal, J. T. Newsom, K. J. Brockwood, and C. L. Colton. 2005. A longitudinal study of the effects of dualearner couples' utilization of family-friendly workplace supports on work and family outcomes. Journal of Applied Psychology 90: 799-810. [CrossRef] [PubMed]

Hayes, Francis. 2013. Methodology in the social sciences. In Introduction to Mediation, Moderation, and Conditional Process Analysis: A Regression-Based Approach. New York: Gulliford Press. [CrossRef]

Howe, David C., Rahul S. Chauhan, Andrew T. Soderberg, and M. Ronald Buckley. 2020. Paradigm shifts caused by the COVID-19 pandemic. Organizational Dynamics, 100804. [CrossRef] [PubMed]

ILO. 2021. Teleworking arrangements during the COVID-19 crisis and beyond. In 2nd Employment Working Group Meeting under the 2021 Italian Presidency of the G20, online, April 14-16. Geneva: International Labour Organization (ILO).

Jostell, David, and Sven Hemlin. 2018. After-hours teleworking and boundary management: Effects on work-family conflict. Work 60: 475-83. [CrossRef]

Karasek, Robert A. 1979. Job Demands, Job Decision Latitude, and Mental Strain: Implications for Job Redesign. Administrative Science Quarterly 24: 285-308. [CrossRef]

Kossek, Ellen Ernst, Boris B. Baltes, and Russell A. Matthews. 2016. Managing work-life boundaries in the digital age. Organizational Dynamics 45: 258-70. [CrossRef]

Kossek, Ellen Ernst, Boris B. Baltes, and Russell A. Matthews. 2011. How work-family research can finally have an impact in the workplace. Industrial and Organizational Psychology 4: 352-59. [CrossRef]

Kreiner, Glen E. 2006. Consequences of work-home segmentation or integration: A person-environment fit perspective. Journal of Organizational Behavior 27: 485-507. [CrossRef]

Ladd, Deborah, and Revecca A. Henry. 2000. Helping Coworkers and Helping the Organization: The Role of Support Perceptions, Exchange Ideology, and Conscientiousness. Journal of Applied Social Psychology 30: 2028-49. [CrossRef]

Madsen, Susan R. 2003. The effects of home-based teleworking on work-family conflict. Human Resource Development Quarterly 14: 35-58. [CrossRef]

Masuda, Aline D., Claudia Holtschlag, and Jessica M. Nicklin. 2017. Why the availability of telecommuting matters: The effects of telecommuting on engagement via goal pursuit. Career Development International 22: 200-19. [CrossRef]

Matias, Marisa, Cláudia Andrade, and Anne Marie Fontaine. 2012. The interplay of gender, work and family in Portuguese families. Work, Organization, Labour and Globalization 6: 11-26. [CrossRef]

Matthews, Russell A., Suzanne M. Booth, Claire F. Taylor, and Tracy Martin. 2011. A qualitative examination of the work-family interface: Parents of children with autism spectrum disorder. Journal of Vocational Behavior 79: 625-39. [CrossRef]

Mesmer-Magnus, Jessica, and Chockalingam Viswesvaran. 2009. The role of the coworker in reducing work-family conflict: A review and directions for future research. Pratiques Psychologiques 15: 213-24. [CrossRef]

Messenger, Jon. 2019. Telework in the 21st Century, An Evolutionary Perspective, an Evolutionary Perspective. The ILO Future of Work Series; Cheltenham: Edward Elgar Publishing. [CrossRef]

Messenger, Jon, Oscar Vargas Llave, Lutz Gschwind, Simon Boehmer, Greet Vermeylen, and Mathijn Wilkens. 2017. Working Anytime, Anywhere: The Effects on the World of Work. Luxembourg and Geneva: Publications Office of the European Union and ILO.

Morganson, Valerie J., Debra A. Major, Kurt L. Oborn, Jennifer M. Verive, and Michelle P. Heelan. 2010. Comparing telework locations and traditional work arrangements: Differences in work-life balance support, job satisfaction, and inclusion. Journal of Managerial Psychology 25: 578-95. [CrossRef]

Parasuraman, Saroj, Yasmin S. Purohit, Veronica M. Godshalk, and Nicholas J. Beutell. 1996. Work and family variables, entrepreneurial career success, and psychological well-being. Journal of Vocational Behavior 48: 275-300. [CrossRef]

Pérez Pérez, Manuela, Angel Martínez Sánchez, Pilar de Luis Carnicer, and María José Vela Jiménez. 2004. A technology acceptance model of innovation adoption: The case of teleworking. European Journal of Innovation Management 7: 280-91. [CrossRef]

Perista, Helosisa, Ana Cardoso, Ana Brázia, Manuel Abrantes, and Pedro Perista. 2016. Os uso do Tempo de Homens e Mulheres em Portugal. Centro de Estudos para a Intervenção Social/Comissão para a Igualdade no Trabalho e no Emprego. Available online: http://cite.gov.pt/pt/destaques/complementosDestqs2/INUT_brochura.pdf (accessed on 7 September 2021).

Piszczek, Matthew M. 2017. Boundary control and controlled boundaries: Organizational expectations for technology use at the work-family interface. Journal of Organizational Behavior 38: 592-611. [CrossRef]

Podsakoff, Philip M., Scott B. MacKenzie, Jeong-Yeon Lee, and Nathan P. Podsakoff. 2003. Common method biases in behavioral research: A critical review of the literature and recommended remedies. Journal of Applied Psychology 88: 879-903. [CrossRef]

Preacher, Kristopher J., and Andrew F. Hayes. 2008. Asymptotic and resampling strategies for assessing and comparing indirect effects in multiple mediator models. Behavior Research Methods 40: 879-91. [CrossRef]

Reifman, Alan, Monica Biernat, and Eric L. Lang. 1991. Stress, social support, and health in married professional women with small children. Psychology of Women Quarterly 15: 431-45. [CrossRef]

Rosenthal, Patrice, David Guest, and Riccardo Peccei. 1996. Gender difference in managers' explanation for their work performance: A study in two organizations. Journal of Occupational and Organizational Psychology 69: 145-51. [CrossRef]

Ruiller, Caroline, Beatrice Van Der Heijden, Frédérique Chedotel, and Marc Dumas. 2019. "You have got a friend": The value of perceived proximity for teleworking success in dispersed teams. Team Performance Management 25: 2-29. [CrossRef]

Santana, Monica, and Manuel J. Cobo. 2020. What is the future of work? A science mapping analysis. European Management Journal 38: 846-62. [CrossRef] 
Saragih, Susanti. 2011. The Effects of Job Autonomy on Work Outcomes: Self Efficacy as an Intervening Variable. International Research Journal of Business Studies 4: 203-15. [CrossRef]

Tavares, Fernando, Eulália Santos, Ana Diogo, and Vanessa Ratten. 2021. Teleworking in Portuguese communities during the COVID-19 pandemic. Journal of Enterprising Communities: People and Places in the Global Economy 15: 334-49. [CrossRef]

Thomas, Linda Thiede, and Daniel C. Ganster. 1995. Impact of family-supportive work variables on work-family conflict and strain: A control perspective. Journal of Applied Psychology 80: 6-15. [CrossRef]

Thompson, Cynthia A., and David J. Prottas. 2006. Relationships among organizational family support, job autonomy, perceived control, and employee well-being. Journal of Occupational Health Psychology 11: 100-18. [CrossRef]

van der Lippe, Tanja, and Zoltán Lippényi. 2020. Co-Workers Working from Home and Individual and Team Performance. New Technology, Work and Employment. Hoboken: Brian Towers (BRITOW) and John Wiley \& Sons Ltd., vol. 35, pp. 60-79. [CrossRef]

Vargas-Llave, Oscar, and Tina Weber. 2020. Regulations to Address Work-Life Balance in Digital Flexible Working Arrangements. New Forms of Employment Series; Luxembourg: Publications Office of the European Union.

Vilhelmson, Bertil, and Eva Thulin. 2016. Who and where are the flexible workers? Exploring the current diffusion of telework in Sweden. New Technology, Work E Employment 31: 77-96. [CrossRef]

Voydanoff, Patricia. 2004. The effects of work demands and resources on work-to-family conflict and facilitation. Journal of Marriage and Family 66: 398-412. [CrossRef]

World Health Organization (WHO). 2020. WHO Director-General's Opening Remarks at the Media Briefing on COVID-19-11 March 2020. Geneva: World Health Organization.

Yu, Rongrong, Matthew Burke, and Nowar Raad. 2019. Exploring impact of future flexible working model evolution on urban environment, economy and planning. Journal of Urban Management 8: 447-57. [CrossRef] 